\title{
Comparative Evaluation for Minerals and Nutritional Elements in Seventeen Marketed Brands of Black Tea of Bangladesh
}

\author{
K M Mesbaul Alam", M K Huda, M A M Chowdhury \\ Laboratory of Plant Ecology, Department of Botany, University of Chittagong, Bangladesh
}

Received December 30, 2019; Revised February 6, 2020; Accepted February 18, 2020

\begin{abstract}
Copyright $\odot 2020$ by authors, all rights reserved. Authors agree that this article remains permanently open access under
\end{abstract} the terms of the Creative Commons Attribution License 4.0 International License

\begin{abstract}
Seventeen marketed brands of black tea of Bangladesh (viz; Seylon, Tetley, Duncan, National, Fresh, Teer, Finlay, Starship, Ispahani, Cosmo, Magnolia, Danish, Shaw Wallace, Pusti, Kazi \& Kazi, HRC and Lipton Taaza tea) randomly collected from the local supermarkets were evaluated for minerals as well as nutritional status. The experiment was done in 2015, 2016 and 2017 for determining the mineral $(\mathrm{N}, \mathrm{P}, \mathrm{K}, \mathrm{Ca}, \mathrm{Na}, \mathrm{Fe})$ and nutritional (sugar, fat, starch and protein) elements. All the studied parameters were found to vary significantly $(\mathrm{P}<0.05)$ with the marketed brands of tea. The average values of mineral compositions ( $\mathrm{N}, \mathrm{P}, \mathrm{K}, \mathrm{Ca}, \mathrm{Na}$ and $\mathrm{Fe}$ ) in Seventeen marketed brands were determined to be $5.11 \%$, $0.24 \%, 2.21 \%, 1.35 \%, 0.16 \%$ and $0.057 \%$ respectively. Whilst the average values of nutritional elements (sugar, fat, starch and protein) were estimated to be $5.72 \%, 1.82 \%$, $0.168 \%$ and $5.41 \%$ respectively. The present study concludes that in considering the total minerals and nutritional status, National tea was evaluated to be the paramount among the studied marketed brands of tea and all the studied brands of black tea were found to be ranked in the order of National $>$ Cosmo $>$ Lipton Taaza $>$ Duncan $>$ Finlay $>$ Ispahani $>$ Magnolia $>$ Shaw Wallace $>$ Seylon $>$ Kazi \& Kazi $>$ HRC $>$ Pusti $>$ Danish $>$ Tetley $>$ Teer $>$ Starship $>$ Fresh. The sequence of minerals and nutritional compositions in all the studied brands of tea followed the sequence of price. The market price of all the studied brands of tea was found to be changed positively with the mineral and nutritional status.
\end{abstract}

Keywords Evaluation, Minerals, Nutritional Elements, Brands, Tea, Bangladesh

\section{Introduction}

Globally, Tea (Camellia sinensis) is second in line after water under popular beverages due to its phenomenal taste and outstanding benefits towards health [1]. Approximately 5000 years ago, tea was first consumed in China for its medicinal properties, while in current era tea had been widely recognized for health benefits pertaining to increased public awareness of the high flavonoid content of the tea leaves and extracts [2,3]. Currently, consumption of tea is part of people's daily routine, as an everyday drink and as a therapeutic aid in many illnesses. Worldwide, $80 \%$ of the tea consumed is black tea, which is also the most popular drink in Europe, North America, and North Africa (except Morocco), whereas green tea is drunk throughout Asia; oolong tea is popular in China and Taiwan [4]. Approximately $76-78 \%$ of the tea produced and consumed worldwide is black tea, $20-22 \%$ is green tea, and $<2 \%$ is oolong tea [5,6]. The installment of tea as a profitable crop has been proved successful worldwide [7]. Currently, it is cultivated in over 30 countries [8].

Tea contains minerals and trace elements such as $\mathrm{K}, \mathrm{Mn}$, $\mathrm{Cr}, \mathrm{Ni}$, and $\mathrm{Zn}$ which are essential to human health. The regular consumption of tea may contribute to the daily dietary requirements of several elements and tea could be an important source of manganese, and the large amount of potassium in comparison with sodium that could be beneficial for hypertensive patients $[9,10]$.

The mineral composition of tea plants depended, not only on the species or varieties, but also on the growing conditions such as soil and geographical condition [11]. Nutrient elements vary in respect to agro-types of tea, geographical origin, environmental conditions and agronomic situation [12]. Satisfactory levels of foliar nitrogen content of the first leaf, second leaf and third leaf 
in the plucked tea shoots are $5.0 \%, 4.4 \%$ and $3.8 \%$ respectively which represent the critical levels [13]. The usual range of leaf phosphorus is between $0.6 \%$ \& $0.9 \%$, $\left(\mathrm{P}_{2} \mathrm{O}_{5}\right)$ and $\mathrm{P}$ content of $0.25 \%$ or less indicates its starvation [14]. The concentration of potassium is higher in two leaves and a bud (about 2.0\%) than the third leaf. Potassium concentration below $1.75 \%$ in first leaf with a bud, and $1.57 \%$ in third leaf are a clear indication that potassium is limiting yield [13]. K values are found to be the highest at 2nd harvest time [15].

Desirable calcium content in North- East India is usually about $0.1 \%$ calcium [16]. Normal tea leaf as plucked contains an average of more than $0.5 \%$ Ca. The concentration of Ca is higher in third leaf (about 1.0\%) than the two leaves and a bud [14]. The earlier study shows that the average sodium content in ten clonal varieties of Bangladesh tea ranged from 0.071-0.118\% [17]. Twig nutrient status was found to change with agrotypes and periods. Na content ranged from $0.068 \%$ to $0.090 \%$, $0.084 \%$ to $0.184 \%$ and $0.058 \%$ to $0.092 \%$ in increasing, peak and decreasing period respectively [17]. The iron content in seven clones of Turkey was investigated by Erturk et. al. [11] during three harvest seasons (May, July and September). The amount of $\mathrm{Fe}$ in tea leaves was the highest at $1^{\text {st }}$ harvest time in Muradiye and Tuglali clones ranging from 0.064 to $0.088 \%$ whilst $\mathrm{Fe}$ was found maximum at $3^{\text {rd }}$ harvest time in Gundogdu, Hamzabey, Hayrat and Pazar 20 clones ranging between 0.068 and $0.090 \%$, respectively. In Enstitu 9 clone the amount of Fe was the highest at $2^{\text {nd }}$ harvest time $(0.022 \%)$.

The mean values of sugar content were determined to be $3.77 \%, 3.45 \%, 4.30 \%$ and $5.16 \%$ in summer, pre-monsoon, monsoon and winter respectively in the various cultivars of South India [18]. Luo and Peng, [19] reported that the fat content was estimated to be $0.88 \%$ to $1.44 \%$ in five black tea samples of China. Good quality black tea is produced from tea leaves from high polyphenols and caffeine contents, relatively low protein content, and an adequate amount of polyphenol oxidase [20]. Robb and Brown [21] and Peterson et al. [22] reported that Protein content in black tea and green tea was determined to be $6.0 \%$ each. Luo and Peng, [19] also reported that the starch content was determined to be $0.027 \%$ to $0.20 \%$ in five black tea samples of China.
So far the literature review is concerned, only few experimental works $[23,24,25]$ on the comparative evaluation of caffeine, polyphenols and antioxidant activity of marketed brands of black tea of Bangladesh have been carried out earlier whereas no research work on the mineral as well as nutritional status of the marketed brands of black tea has yet been done. But a number of tea companies have been marketing a number of their products under different trade names and commercial values. So it is a big question for the area of tea research in Bangladesh whether all the marketed brands of black tea possess the standard level of minerals as well as nutritional status or not. With this view in mind a laboratory analyses was undertaken to evaluate the comparative status of minerals and nutritional elements of seventeen marketed brands of black tea of Bangladesh.

\section{Materials and Methods}

\subsection{Collection of Commercial Tea Samples}

Seventeen different commercial brands of black Tea (produced in Bangladesh) namely Seylon tea, Tetley tea, Duncan tea, National tea, Fresh tea, Teer tea, Finlay Premium tea, Starship tea, Ispahani tea, Cosmo tea, Magnolia tea, Danish tea, Shaw Wallace tea, Pusti tea, Kazi \& Kazi tea, HRC tea and Lipton Taaza tea were collected from Bangladesh Tea Expo 2017, Dhaka and various super shops of Chittagong city. All the commercial brands of tea were mentioned in the present study as "marketed brands of tea".

\subsection{Laboratory Work}

Analytical preparation: All the glassware's were soaked overnight with chromic acid solution and washed thoroughly with water and detergent, then rinsed with deionized water before use. The chemicals and reagents used in this study were of high quality. The tea samples were kept at room temperature throughout the analyses. 
Table 1. Price list of seventeen marketed brands of black tea of Bangladesh along with manufacturing and expiry date

\begin{tabular}{|c|c|c|c|c|c|c|}
\hline Brand Name & Collected from & $\begin{array}{l}\text { Manufacturing } \\
\text { Date }\end{array}$ & Expiry Date & $\begin{array}{c}\text { Weight } \\
\text { (g) }\end{array}$ & $\begin{array}{c}\text { MRP } \\
\text { Tk }\end{array}$ & $\begin{array}{l}\text { MRP } \\
\text { Tk/kg }\end{array}$ \\
\hline Seylon Gold Tea & Super market & $22 / 02 / 2017$ & $21 / 02 / 2019$ & 10 & 5 & 500 \\
\hline Tetley Premium Leaf Tea & Super market & 26/10/2016 & 26/10/2018 & 200 & 85 & 425 \\
\hline Duncan’s Tea & Tea Expo’17 & 23/12/2016 & 23/12/2018 & 100 & 50 & 500 \\
\hline National Tea & Теa Ехро’17 & 08/01/2017 & 08/01/2018 & 10 & 5 & 500 \\
\hline Fresh Premium Tea & Super market & $27 / 04 / 2016$ & $26 / 04 / 2018$ & 200 & 75 & 375 \\
\hline Teer Tea & Super market & 21/05/2016 & $21 / 05 / 2018$ & 50 & 18 & 320 \\
\hline Finlay premium Tea & Finlay House & 18.11.2016 & 17.11 .2018 & 500 & 220 & 440 \\
\hline Star Ship Special Tea & Super market & 17/04/2016 & $16 / 04 / 2018$ & 500 & 158 & 316 \\
\hline Ispahani Zareen Tea & Super market & 27/03/2016 & $27 / 02 / 2018$ & 200 & 88 & 440 \\
\hline Cosmo Tea & Tea Expo’17 & $12 / 07 / 2016$ & $12 / 07 / 2018$ & 50 & 30 & 600 \\
\hline Magnolia Tea & Tea Expo’17 & 15/05/2016 & $06 / 02 / 2017$ & 10 & 5 & 500 \\
\hline Danish BOP Tea & Super market & 29/12/2015 & $30 / 12 / 2017$ & 500 & 149 & 298 \\
\hline Shaw Wallace Super Clone & SW Trade Centre & $10 / 01 / 2017$ & $10 / 12 / 2018$ & 200 & 99 & 500 \\
\hline Pusti BOP Tea & Super market & 04/05/2016 & $03 / 05 / 2018$ & 500 & 149 & 298 \\
\hline Kazi \& Kazi & Super market & $23 / 11 / 2016$ & $22 / 05 / 2018$ & 200 & 130 & 650 \\
\hline HRC Premium Tea & Tea Expo’17 & 15/02 2017 & $15 / 01 / 2019$ & 500 & 173 & 346 \\
\hline Lipton Taaza & Super market & $03 / 04 / 2017$ & $02 / 04 / 2019$ & 200 & 85 & 425 \\
\hline
\end{tabular}

\subsection{Determination of $\mathrm{N}, \mathrm{P}, \mathrm{K}, \mathrm{Ca}$ and Na Contents of Tea}

Nitrogen was determined by Micro-Kjeldahl distillation method [26]. Phosphorus was determined by spectrophotometric method [27]. Potassium, sodium and calcium were determined by flame photometric method [28].

\subsection{Determination of Total Iron (Fe) Content in Black Tea}

Material: Tea samples were prepared by wet digestion (open system) where weighed mass of $1.0 \mathrm{~g}$ was heated with mixture of concentrated Nitric acid and Sulfuric acid for 4 hours at temperatures $110-130^{\circ} \mathrm{C}$. Solid phase separated by filtration (blue filtered paper), dissolved in mixture of Nitric and Hydrochloric acids (concentration of $0.05 \mathrm{~mol} / \mathrm{l}, 1: 1 \mathrm{v} / \mathrm{v})$, transferred in volumetric flask $(100 \mathrm{~mL})$ and diluted to mark with same mixture of acids. Digestion of each sample was done in triplicate.
Spectrophotometric method: Spectrophotometric method was performed with a UV-visible spectrophotometer (Shimadzu UV-160A PC, Shimadzu Corporation, Kyoto, Japan). Solutions of prepared samples were yellow to pale red color. Before spectrophotometric analysis, intensity of color was increased by addition of potassium thiocyanate (Sigma- Aldrich Co. LLC) for complexion of Iron ions and formation of red complex with different composition from $\left[\mathrm{FeSCN}\left(\mathrm{H}_{2} \mathrm{O}\right)_{5}\right]^{2}+$ to $\left[\mathrm{Fe}(\mathrm{SCN})_{6}\right]^{3}$.

Standard stock solutions of Iron(III) ions was prepared by dissolving $20 \mathrm{mg}$ of Iron (III) chloride (Sigma-Aldrich Co. LLC) in $100 \mathrm{ml}$ deionized water in a volumetric flask $(100 \mathrm{ml})$. The calibration solutions were prepared by pipetting volumes of $0.05,0.10,0.25,0.50,0.75,1.00,1.50$, 2.00 and $2.50 \mathrm{ml}$, respectively of the stock standard solution into volumetric flasks (10 ml) (Appendix 5). Next, of volumes of $1.00 \mathrm{ml}$ of nitric acid and $1.20 \mathrm{ml}$ of Potassium thiocyanate (concentration of both solution was $5 \mathrm{M}$ ) were added to each volumetric flasks to obtain a concentration range from 1.40 to $69.81 \mu \mathrm{g} / \mathrm{ml} \mathrm{Fe}$. The 
absorbance of each solution (working and analyzed solutions) was measured at absorption maximum of 481.0 nm using 190 mm -2500 mm quartz cuvette.

\subsection{Measurement of Total Sugar Content Using Anthrone Colorimetry}

Standard curve: Seven dry clean tubes were taken and numbered them; then added standard glucose, tri-distilled water, anthrone reagent in turn into the tubes and put them in boiling water for 10 minutes. After that, moved them quickly into icy water to cooled down, then put them in the dark for 10 minutes to test the absorbance in wave length of $620 \mathrm{~nm}$. Draw a coordinate graph with absorbance for $\mathrm{Y}$-ordinate and standard solution concentration $(\mathrm{mg} / \mathrm{ml})$ for $\mathrm{X}$-ordinate.

Pre-processing of the samples: Weighed accurately each sample for $0.5 \mathrm{~g}$, and put them into a $50 \mathrm{ml}$ conical flask; then added $20 \mathrm{ml}$ tri-distilled water to dissolve them followed by adding $10 \mathrm{ml}$ solution of lead subacetate, and shook well till light yellow precipitation appears, then put them still for 10 minutes; added $10 \mathrm{ml}$ solution of sodium sulphate and shook well; at last, centrifuged them in 1000 $\mathrm{r} / \mathrm{min}$ for 15 minutes, then taken the upper clear liquid to make $100 \mathrm{ml}$ solution for reserve.

Content determination and calculation: All the samples were taken got from pre-processing, and each sample needed three parallel experiments of which each parallel experiment needed three repetitions. Nine dry clean tubes were taken and numbered them; then added sample solution, tri-distilled water, anthrone reagent in turn into the tubes and put them in boiling water for 10 minutes. After that, moved them quickly into icy water to cooled down, then put them in the dark for 10 minutes to test the absorbance in wave length of $620 \mathrm{~nm}$. According to the formula (w: sugar mass fraction (\%); C: sugar mass fraction from standard curve $(\mathrm{mg} / \mathrm{ml}) ; V$ : the sample's volume after dilution (ml); $M$ : the sample quality (mg)), calculate the sugar content in each sample [19].

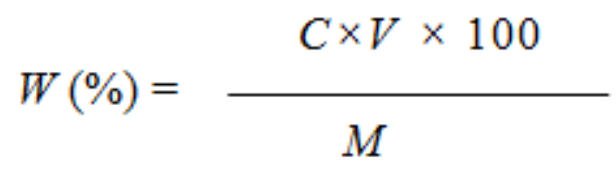

\subsection{Determination of Fat Using Acid Hydrolysis}

Each sample for $1.0 \mathrm{~g}$ was weighed accurately, and put them into a $50 \mathrm{ml}$ conical flask with adding water $8 \mathrm{ml}$ and hydrochloric acid $10 \mathrm{ml}$; then put the conical flask into $75^{\circ} \mathrm{C}$ constant temperature water bath for 90 minutes with mixing them at every 5 minutes till the sample completely dissolved. Put in ethanol (95\%) 10ml, and after the sample cooled down, transferred it into the separatory funnel; took ether $25 \mathrm{ml}$ to wash the conical flask in times, then transferred it into the separatory funnel followed by shaking out with plug for 1 minutes. Put it still without the plug for 12 minutes, then added $10 \mathrm{ml}$ mixture of ether and equivalent petroleum ether to wash the fat sticked on the bottle stopper and surrounding place; put it still for 20 minutes after shaking it out with the plug. Skimmed the liquid after it became different layered by letting the lower layer of liquid out from the funnel mouth and sucked out the upper layer of liquid. Put upper layer of liquid into constant-weight conical flask and lower layer of liquid into separatory funnel for skimming with sucking up upper layer into constant-weight conical flask. Put the conical flask into $60^{\circ} \mathrm{C}$ water to dry it, and then baked it 2 hours in $100^{\circ} \mathrm{C}$ oven followed by putting it in the dryer for 30 minutes; then weighed it and recorded the data. Repeated the above steps until the conical flask kept constant weight [19].

Calculation formula

$$
x(\%)=\frac{\left(m_{1}-m_{0}\right) \times 100}{m_{2}}
$$

$x$ : fat content in the sample (\%);

$m_{l}$ : conical flask and the fat quality (g);

$m_{0}$ : the conical flask's quality (g);

$m_{2}$ : the sample's quality (g).

\subsection{Determination of Starch Content Using Acid Hydrolysis}

Processing of the sample: Each sample for $2.0 \mathrm{~g}$ weighed accurately and repeated twice; put them in dry clean Petri dishes which were next put into drying oven. Washed and cleaned the fat in the sample with $30 \mathrm{ml}$ ether; waited till the ether fully volatilized, then washed it with $150 \mathrm{ml}$ ethanol to remove the reducing sugar.

Preparation of sample solution: $100 \mathrm{ml}$ tri-distilled water was taken to wash the residue from last step into a $250 \mathrm{ml}$ conical flask; jointed it to condenser pipe after adding 30 $\mathrm{ml}$ hydrochloric acid into it and put it in boiling water for reflux for 2 hours; when it cooled down, added 2 drops of methyl red and drip with $\mathrm{NaOH}$ to adjust the $\mathrm{PH}$ as 7 . Shook it out and put it still for 10 minutes after adding 20 $\mathrm{ml}$ lead acetate $(200 \mathrm{~g} / \mathrm{l})$; then put in $20 \mathrm{ml}$ sodium sulphate $(100 \mathrm{~g} / \mathrm{l})$ to remove excess lead; got $500 \mathrm{ml}$ liquid out of it and the upper clear solution from centrifugal was the sample solution.

The calibration of alkaline tartaric acid copper solution: Three parallel experiments were set by taking alkaline tartaric acid copper solution A $5 \mathrm{ml}$ and solution B $5 \mathrm{ml}$ into a $150 \mathrm{ml}$ conical flask, and added tri-distilled water $10 \mathrm{ml}$ 
and 2 grains of glass beads. Added glucose standard solution $9 \mathrm{ml}$ into an acid burette, and heated the conical flask until it boiled for 2 minutes, then dropped the glucose standard solution with a speed of $2 \mathrm{~s} / \mathrm{d}$ until the blue colour of the solution fades away; wrote down the total volume of the standard solution required.

The prediction of the test sample solution: Each sample solution was taken for $10 \mathrm{ml}$ respectively, and put alkaline tartaric acid copper solution A $5 \mathrm{ml}$ and solution B $5 \mathrm{ml}$ into a $150 \mathrm{ml}$ conical flask; dripped the glucose standard solution just until the blue colour faded away and wrote down glucose volume by consumption; the formula for predicting the volume is $\left(V_{1}\right.$ : the glucose volume by consumption in dripping; $V_{2}$ : the volume of glucose by consumption in prediction). The determination of test sample solution: set two parallel experiments for each sample; add alkaline tartaric acid copper solution A $5.0 \mathrm{ml}$ and solution B $5.0 \mathrm{ml}$ each time, and tri-distilled water 10 $\mathrm{ml}$; heated it until it boiled; continue to drop sample solution while it was still hot until the blue colour just faded away; wrote down the volume of sample solution by consumption [19].

$$
V(\%)=\frac{\left(\underline{V}_{1}-\frac{V_{2}}{2}\right) \times V_{2}}{10 \times V_{1}}
$$

\subsection{Determination of Protein Content}

The slaking of the sample: First, the concentration of sulfuric acid standard solution was set down; weighed respectively the sample for $0.5 \mathrm{~g}$, and put it into a dry 250 $\mathrm{ml}$ nitrogen bottle; added copper sulphate $0.1 \mathrm{~g}$, potassium sulphate $1.0 \mathrm{~g}$ and sulfuric acid $10 \mathrm{ml}$, then shook well followed by heating it on an electric heater; the solution appeared reddish brown after 2 hours and appeared transparent blue-green after 3 hours; continued heating for 0.5 hour, then cooled it down and added tri-distilled water $20 \mathrm{ml}$; made it to be $100 \mathrm{ml}$ solution. Three parallel experiments and blank as control for each sample were done.

The alkalization-distillation of the sample: Installed the nitrogen device, added water to two-third of the water vapor reaction bottle; put in methyl red $5 \mathrm{ml}$ and sulphuric acid $5 \mathrm{ml}$; heated it and washed the reaction device with boiling water. After the washing, put sample solution $10 \mathrm{ml}$ (or blank liquid) into the reaction tube and inserted the ground stopper; added $2 \%$ boric acid $25 \mathrm{ml}$ into a $250 \mathrm{ml}$ conical flask, and put it to the bottom of the condenser pipe; added $20 \% \mathrm{NaOH}$ solution $20 \mathrm{ml}$ into the reaction tube from the mouth for adding sample to make the sample solution in the reaction tube formed black precipitation or became dark blue; then washed the mouth with tri-distilled water, inserted the ground stopper, and sealed the mouth with some water. Retained the vapour in the reaction tube for 10 minutes of distillation, lifted the bottom of the condenser piped off the absorption liquid surface, and distillated for one minute; used naphthalene's reagent to test it, and if there was no ammonia, then stopped undertaking distillation liquid and discharged the waste liquor; washed the device.

Titration and calculation of the outcomes: Accurately sucked up $10 \mathrm{ml}$ sample slaking solution into the reaction chamber; moved the conical flask after 9 minutes' distillation, and after another 4 minutes distillation, the colour of boric solution changed from colorless to green; another 5 minutes distillation, moved the conical flask and made the liquid away from the bottom of condenser pipe; another 1 minute of distillation, washed the outside of the condenser's bottom with some water. Conical flask was taken and titrated it to colorless with sulfuric acid standard titration solution. Marked the consumed volume of sulphate as $V_{1}$, the volume of sulphate consumed by blank slaking solution as $V_{2}$, and test each sample slaking solution 3 times. Here's the formula: ( $C$ : concentration of sulfuric acid standard solution mol/L; V1: the volume of sulphuric acid standard solution consumed by titrating the sample absorption solution $\mathrm{ml} ; V_{2}$ : the volume of sulfuric acid standard solution consumed by titrating the sample blank solution $\mathrm{ml}$; $M$ : the quality of tea polyphenol (g); F: the conversion coefficient of protein content in tea polyphenol (6.25) [19].

$$
\operatorname{Protein}(\%)=\frac{\mathrm{C} \times\left(V_{1}-V_{2}\right) \times 0.01401 \times \mathrm{F} \times 100}{\frac{M \times 10}{100}}
$$

\subsection{Statistical Analysis}

All measurements were carried out in triplicate forms. Results of the parameter determined were expressed as a mean of the triplicate determination. The data was analysed using the one-way analysis of variance (ANOVA) tool under the Statistical Package Social Science (SPSS) 16.0 software. The ANOVA and Duncan's Multiple Range test (DMRT) were completed to compare the mean values and standard deviation among the samples.

\section{Results and Discussion}

\subsection{Nitrogen (N)}

The results authenticate that all the minerals and nutritional elements studied so far in the present experiment varied significantly $(\mathrm{P}<0.05)$ with the brands. Maximum amount of nitrogen was estimated to be $6.24 \%$ in National tea and minimum amount was estimated to be $3.87 \%$ in Starship tea. The mean value of nitrogen content of the studied brands was found to be $5.11 \%$ (Table 2). Nitrogen content $(\mathrm{N})$ of the studied brands of tea was found 
to be positive significantly $(\mathrm{P}<0.05)$ correlated with $\mathrm{P}, \mathrm{K}$, $\mathrm{Ca}, \mathrm{Na}, \mathrm{Fe}, \mathrm{Fat}$ and Protein but negative significantly $(\mathrm{P}<$ $0.05)$ correlated with starch content. Nitrogen content did not show any significant correlation with sugar content (Table 4). It is previously reported that $\mathrm{N}$ content of tea leaves were between 3.0-4.0\% [29] which is in agreement with our results. Nitrogen content was investigated in seven marketed teas of Shaw Wallace brand produced in Bangladesh and nitrogen was found to be maximum in Danadar tea (5.14\%) and minimum in Fine Dust tea (4.52\%) [30].This result is comparable to the findings of the present experiment.

Alam et al. [31] worked on the nutritional elements in six marketed brands of Ispahani tea grown in Bangladesh and maximum concentration of nitrogen was determined to be $5.7 \%$ in Best Quality (BOP) tea and minimum concentration was $3.9 \%$ in Blender's Choice tea. This opinion is substantial with the nitrogen status of the present study. Alam et al. [32] investigated the qualitative status of eight commercialized teas of Finlay brand grown in
Bangladesh. They reported that maximum concentration of nitrogen was estimated to be $5.21 \%$ in English Breakfast Tea Bag and minimum concentration was estimated to be $4.07 \%$ in BOP. This report is consistent with the present study.

Mineral nutritional status in six marketed teas of Kazi \& Kazi brand grown in Bangladesh was studied by Alam et al. [32]. They reported that the highest amount of nitrogen content was determined to be $5.25 \%$ in Orthodox black tea and the lowest amount was determined to be $4.24 \%$ in Ginger tea which is in full consensus with results of the present investigation. Hence, it is evident that nitrogen content in the marketed teas of Bangladesh is as good as the national and international benchmark and except the Starship tea, all other studied brands might have maintained the qualitative standard so far the nitrogen content is concerned. Subsequently, National tea was found to be considered as the best marketed tea of Bangladesh in relation to nitrogen content.

Table 2. Variation of nutritional elements (N, P, K, Ca, Na and Fe) in seventeen marketed brands of black tea of Bangladesh

\begin{tabular}{|c|c|c|c|c|c|c|}
\hline Brands & $\mathrm{N}(\%)^{\dagger}$ & $\mathrm{P}(\%)^{\dagger}$ & $\mathrm{K}(\%)^{\dagger}$ & $\mathrm{Ca}(\%)^{\dagger}$ & $\mathrm{Na}(\%)^{\dagger}$ & $\mathrm{Fe}(\%)^{\dagger}$ \\
\hline Seylon & $5.26 \pm 0.31 \mathrm{de}$ & $0.23 \pm 0.08 \mathrm{a}$ & $2.11 \pm 0.45 \mathrm{a}$ & $1.18 \pm 0.26 \mathrm{a}$ & $0.08 \pm 0.012 \mathrm{ab}$ & $0.046 \pm 0.009 a b$ \\
\hline Tetley & $5.13 \pm 0.29 \mathrm{~d}$ & $0.20 \pm 0.08 \mathrm{a}$ & $2.15 \pm 0.46 \mathrm{a}$ & $1.22 \pm 0.25 \mathrm{a}$ & $0.09 \pm 0.020 \mathrm{abc}$ & $0.051 \pm 0.011 \mathrm{abc}$ \\
\hline Duncan & $5.67 \pm 0.26$ ef & $0.25 \pm 0.07 \mathrm{a}$ & $2.31 \pm 0.51 \mathrm{a}$ & $1.38 \pm 0.29 \mathrm{a}$ & $0.18 \pm 0.070$ abcde & $0.062 \pm 0.018$ abcde \\
\hline National & $6.24 \pm 0.29 \mathrm{~g}$ & $0.31 \pm 0.06 \mathrm{a}$ & $2.38 \pm 0.50 \mathrm{a}$ & $1.53 \pm 0.28 \mathrm{a}$ & $0.25 \pm 0.120 \mathrm{e}$ & $0.083 \pm 0.522 \mathrm{e}$ \\
\hline Fresh & $4.25 \pm 0.22 \mathrm{abc}$ & $0.18 \pm 0.07 \mathrm{a}$ & $1.95 \pm 0.44 \mathrm{a}$ & $1.21 \pm 0.25 \mathrm{a}$ & $0.07 \pm 0.008 \mathrm{a}$ & $0.037 \pm 0.005 \mathrm{a}$ \\
\hline Teer & $4.06 \pm 0.24 \mathrm{ab}$ & $0.19 \pm 0.07 \mathrm{a}$ & $2.08 \pm 0.45 \mathrm{a}$ & $1.25 \pm 0.24 \mathrm{a}$ & $0.09 \pm 0.020 \mathrm{abc}$ & $0.043 \pm 0.005 \mathrm{ab}$ \\
\hline Finlay & $5.34 \pm 0.24$ de & $0.27 \pm 0.09 \mathrm{a}$ & $2.28 \pm 0.44 \mathrm{a}$ & $1.45 \pm 0.34 \mathrm{a}$ & $0.21 \pm 0.105$ bcde & $0.076 \pm 0.010 \mathrm{de}$ \\
\hline Starship & $3.87 \pm 0.22 \mathrm{a}$ & $0.20 \pm 0.08 \mathrm{a}$ & $2.05 \pm 0.48 \mathrm{a}$ & $1.23 \pm 0.25 \mathrm{a}$ & $0.10 \pm 0.024$ abcd & $0.043 \pm 0.006 \mathrm{ab}$ \\
\hline Ispahani & $5.66 \pm 0.29$ ef & $0.24 \pm 0.07 \mathrm{a}$ & $2.22 \pm 0.51 \mathrm{a}$ & $1.41 \pm 0.30 \mathrm{a}$ & $0.20 \pm 0.075$ abcde & $0.064 \pm 0.020$ bcde \\
\hline Cosmo & $5.97 \pm 0.26 \mathrm{fg}$ & $0.26 \pm 0.08 \mathrm{a}$ & $2.33 \pm 0.42 \mathrm{a}$ & $1.48 \pm 0.29 \mathrm{a}$ & $0.23 \pm 0.080$ de & $0.066 \pm 0.020$ bcde \\
\hline Magnolia & $5.56 \pm 0.25 \mathrm{def}$ & $0.28 \pm 0.07 \mathrm{a}$ & $2.30 \pm 0.42 \mathrm{a}$ & $1.44 \pm 0.27 \mathrm{a}$ & $0.19 \pm 0.100$ abcde & $0.062 \pm 0.016$ abcde \\
\hline Danish & $4.42 \pm 0.26$ bc & $0.17 \pm 0.07 \mathrm{a}$ & $2.18 \pm 0.48 \mathrm{a}$ & $1.17 \pm 0.26 \mathrm{a}$ & $0.11 \pm 0.039$ abcd & $0.048 \pm 0.007 \mathrm{abc}$ \\
\hline Shaw Wallace & $5.36 \pm 0.30 \mathrm{de}$ & $0.30 \pm 0.08 \mathrm{a}$ & $2.26 \pm 0.47 \mathrm{a}$ & $1.36 \pm 0.28 \mathrm{a}$ & $0.18 \pm 0.075$ abcde & $0.058 \pm 0.014$ abcd \\
\hline Pusti & $4.47 \pm 0.28$ bc & $0.22 \pm 0.08 \mathrm{a}$ & $2.21 \pm 0.38 \mathrm{a}$ & $1.27 \pm 0.23 \mathrm{a}$ & $0.12 \pm 0.047$ abcde & $0.041 \pm 0.008 \mathrm{ab}$ \\
\hline Kazi \& Kazi & $5.35 \pm 0.24$ de & $0.23 \pm 0.08 \mathrm{a}$ & $2.27 \pm 0.39 \mathrm{a}$ & $1.46 \pm 0.35 \mathrm{a}$ & $0.17 \pm 0.075$ abcde & $0.059 \pm 0.007$ abcde \\
\hline HRC & $4.56 \pm 0.22 \mathrm{c}$ & $0.22 \pm 0.09 \mathrm{a}$ & $2.24 \pm 0.45 \mathrm{a}$ & $1.42 \pm 0.30 \mathrm{a}$ & $0.16 \pm 0.075$ abcde & $0.054 \pm 0.011$ abcd \\
\hline Lipton Taaza & $5.72 \pm 0.24$ ef & $0.29 \pm 0.08 \mathrm{a}$ & $2.32 \pm 0.37 \mathrm{a}$ & $1.49 \pm 0.28 \mathrm{a}$ & $0.22 \pm 0.080$ cde & $0.071 \pm 0.019$ cde \\
\hline Mean & $5.11 \pm 0.72$ & $0.24 \pm 0.08 \mathrm{a}$ & $2.21 \pm 0.39$ & $1.35 \pm 0.26$ & $0.16 \pm 0.081$ & $0.057 \pm 0.130$ \\
\hline
\end{tabular}

${ }^{\dagger}$ Means (n=3) in table followed by a common letter are not significantly different $(\mathrm{P}>0.05)$. 


\subsection{Phosphorus (P)}

The highest amount of phosphorus content was determined to be $0.31 \%$ in National tea and the lowest amount was determined to be $0.17 \%$ in Danish tea. The mean value of phosphorus content of the studied brands was found to be $0.24 \%$ (Table 2). Phosphorus content (P) of the studied brands of tea was found to be positive significantly $(\mathrm{P}<0.05)$ correlated with $\mathrm{N}, \mathrm{K}, \mathrm{Ca}, \mathrm{Na}, \mathrm{Fe}$, Fat and Protein but negative significantly $(\mathrm{P}<0.05)$ correlated with starch content (Table 4). Phosphorus status of the present experiment corroborates with the findings of Ozgumus et al. [33] who found that P content of tea leaves grown in Turkey was between $0.31-0.40 \%$. Phosphorus content was investigated in seven marketed teas of Shaw Wallace brand produced in Bangladesh and Phosphorus was found to be the highest in Premium tea bag $(0.28 \%)$ and the lowest concentration was found in Fine Dust tea $(0.17 \%)$ [30].This result is substantial with the findings of the present experiment.

Alam et. al. [34] worked on the nutritional elements in six marketed brands of Ispahani tea grown in Bangladesh and the highest amount of Phosphorus content was detected to be $0.175 \%$ in Best Quality (PD) tea and the lowest amount was detected to be $0.125 \%$ in Blender's choice tea. This result is generous to the Phosphorus status of the present study. Alam et. al. [32] investigated the qualitative status of eight commercialized teas of Finlay brand grown in Bangladesh. She reported that maximum concentration of Phosphorus was estimated to be $0.33 \%$ in English Breakfast Tea Bag and minimum concentration was estimated to be $0.19 \%$ in BOP. This report is consistent with the findings of present study.

Mineral status in six marketed teas of Kazi \& Kazi brand grown in Bangladesh was studied by Alam et. al. [35]. They reported that the highest amount of Phosphorus content was estimated to be $0.25 \%$ in Tulsi tea and the lowest amount was determined to be $0.12 \%$ in Black tea which is in full harmony with the results of the present experiment. So far the Phosphorus content is concerned, all the tested brands demonstrated reasonably high amount of Phosphorus content which covers the level of Bangladesh tea standard and certainly comparable with that of the other tea producing countries. Therefore, Present study suggests that National brand tea is superior in respect to Phosphorus content among the studied marketed brands of tea in Bangladesh.

\subsection{Potassium (K)}

Maximum amount of potassium content was detected to be $2.38 \%$ in National tea and minimum amount was detected to be $1.95 \%$ in Fresh tea. The mean value of potassium content of the studied brands was calculated to be $2.21 \%$ (Table 2). Potassium content $(\mathrm{K})$ of the studied brands of tea showed positive significant $(\mathrm{P}<0.05)$ correlation with N, P, Ca, Na, Fe, Fat and Protein but showed negative significant $(\mathrm{P}<0.05)$ correlation with starch content (Table 4). Potassium status of the present experiment corroborates with the findings of Adnan et al. [36] who found that Potassium content ranged from 3.01 to $4.00 \%$ in the ten popular commercial tea brands collected from different cities of Pakistan.

Potassium content was investigated in seven marketed teas of Shaw Wallace brand produced in Bangladesh and the maximum concentration were found in Danadar (2.05\%) and minimum concentration were in Fine Dust (1.55\%) [30].This result is in accordance with the findings of the present experiment. Alam et al. [34] worked on the nutritional elements in six marketed brands of Ispahani tea grown in Bangladesh and Potassium content was estimated to be maximum in Best quality (BOP) tea (2.85\%) and minimum in Zareen tea (1.24\%). This result is consistent with the Potassium status of the present study.

Alam et al. [32] investigated the qualitative status of eight commercialized teas of Finlay brand grown in Bangladesh. She reported that the highest concentration potassium was found in English Breakfast Tea Bag (2.15\%) and the lowest concentration was found in Finlay Tea Bag (1.47\%). These report similitudes with the findings of present study. Mineral nutritional status in six marketed teas of Kazi \& Kazi brand grown in Bangladesh was studied by Alam et al. [35]. They reported that the highest amount of potassium content was estimated to be $2.85 \%$ in Black tea and the lowest amount was determined to be $1.64 \%$ in Ginger tea which is in full agreement with the results of the present experiment. Finally, in considering the potassium content, all the studied brands demonstrated persuasively high amount of potassium which covers the level of Bangladesh tea standard and indubitably analogous to the standard of other tea producing countries. Therefore, Present study recommends that National brand tea would be considered as superior in relation to potassium content among the studied marketed brands of tea in Bangladesh.

\subsection{Calcium (Ca)}

The highest amount of calcium content was determined to be $1.53 \%$ in National tea and the lowest amount was determined to be $1.17 \%$ in Danish tea. The mean value of calcium content of the studied brands was calculated to be $1.35 \%$ (Table 2). Calcium content (Ca) of the studied brands of tea was found to be positive significantly ( $\mathrm{P}<$ 0.05 ) correlated with N, P, Ca, Na, Fe, Fat and Protein but negative significantly $(\mathrm{P}<0.05)$ correlated with starch content (Table 4). Calcium status of the present experiment substantiates with the findings of Adnan et al. [36] who found that Potassium content ranged from 1.46 to 2.81\% with an average of $1.99 \%$ in ten popular commercial tea brands collected from different cities of Pakistan.

Calcium content was investigated in seven marketed teas of Shaw Wallace brand produced in Bangladesh and the 
maximum amount was found in Danadar (1.37\%) and minimum amount was found in Fine Dust (0.65\%) [30].This result is in agreement with the findings of the present experiment. Alam et al. [34] worked on the nutritional elements in six marketed brands of Ispahani tea grown in Bangladesh and calcium content was estimated to be maximum in Blender's choice tea $(1.75 \%)$ and minimum in Best Quality (PD) tea (1.24\%). This result is consistent with the Potassium status of the present study.

Alam et al. [32] investigated the qualitative status of eight commercialized teas of Finlay brand grown in Bangladesh. They reported that maximum Ca concentration was found in GOLD Tea (1.52\%) whilst minimum was in Dust (WP) $(0.76 \%)$. This report corroborates with the findings of present study. Mineral nutritional status in six marketed teas of Kazi \& Kazi brand grown in Bangladesh was studied by Alam et al. [35]. They reported that the highest amount of calcium content was determined to be $1.75 \%$ in Orthodox black tea and the lowest amount was determined to be $1.24 \%$ in Tulsi tea which is in full agreement with the results of the present experiment. The standing of calcium content in the Present study is a similar to those above mentioned research results. In conclusion, it is clear from the results that calcium content of the marketed brand teas of Bangladesh is better comparable with the standard of other countries and National tea would be considered as the best one in Bangladesh while calcium content is concerned.

\subsection{Sodium (Na)}

Maximum amount of sodium content was estimated to be $0.25 \%$ in National tea and minimum amount was estimated to be $0.07 \%$ in Fresh tea. The mean value of sodium content of the studied brands was calculated to be $0.16 \%$ (Table 2). Sodium content $(\mathrm{Na})$ of the studied brands of tea was found to be positive significantly $(\mathrm{P}<$ 0.05 ) correlated with N, P, Ca, Na, Fe, Fat and Protein but negative significantly $(\mathrm{P}<0.05)$ correlated with sugar and starch content (Table 4). Sodium status of the present experiment substantiates with the findings of Adnan et al. [36] who found that sodium content ranged from 0.039 to $0.083 \%$ with an average of $0.050 \%$ in ten popular commercial tea brands collected from different cities of Pakistan.

Calcium content was investigated in seven marketed teas of Shaw Wallace brand produced in Bangladesh and maximum $\mathrm{Na}$ content was determined in Danadar tea $(0.17 \%)$ and minimum was in Fine Dust tea $(0.07 \%)$ [30]. This result is consistent with the findings of the present experiment. Alam et al. [34] worked on the nutritional elements in six marketed brands of Ispahani tea grown in Bangladesh and maximum amount of sodium content was estimated to be $0.089 \%$ in Blender's choice and minimum was $0.058 \%$ in Best leaf. This result is in accordance with the sodium status of the present study.
Alam et al. [32] investigated the qualitative status of eight commercialized teas of Finlay brand grown in Bangladesh. They reported that maximum Na content was found in English Breakfast Tea Bag (0.19\%) and minimum was found in Finlay Tea (0.08\%). This report also corroborates with the findings of present study. Mineral nutritional status in six marketed teas of Kazi \& Kazi brand grown in Bangladesh was studied by Alam et al. [35]. They reported that the highest amount of sodium content was determined to be $0.090 \%$ in black tea and the lowest amount was determined to be $0.051 \%$ in Ginger tea which is in full agreement with the results of the present experiment. In fine, it is evident from the results that sodium content of the marketed brand teas of Bangladesh is a bit higher than the other countries and National tea would be regarded as the best commercialized tea in Bangladesh in relation to sodium content.

\subsection{Iron (Fe)}

The highest amount of iron content was determined to be $0.083 \%$ in National tea and the lowest amount was determined to be $0.037 \%$ in Fresh tea. The mean value of iron content of the studied brands was calculated to be $0.057 \%$ (Table 2). Iron content (Fe) of the studied brands of tea was found to be positive significantly $(\mathrm{P}<0.05)$ correlated with N, P, Ca, Na, Fe, Fat and Protein but negative significantly $(\mathrm{P}<0.05)$ correlated with sugar and starch content (Table 4). A previous report showed that the Fe concentrations in imported teas in Czech Republic varied from 0.037 to $0.142 \mathrm{mg} / \mathrm{mL}$ [37] which are consistent with the results of present study.

Black teas from the markets of India [38] and Nigeria [39] were reported to have Fe contents of $0.439 \mathrm{mg} / \mathrm{mL}$ and 0.99 to $2.39 \mathrm{mg} / \mathrm{mL}$, respectively. This report also corroborates with the findings of the present investigation. The highest value of Fe was found to be $2.396 \pm 0.040 \mathrm{mg} / \mathrm{L}$ in black teas from the market from Turkey [40] which is comparable to the Fe status of the present experiment. Mandal et al. [41] estimated that the black tea products collected from the markets of Bosnia and Herzegovina contained Fe concentrations as 37.6, 21.3, 29.01 and 27.40 $\mathrm{mg} / \mathrm{kg}$ in Ceylon tea, Hazir Harman Cay, Indian black tea and Ceylon tea extra quality respectively which is in accordance with the results of present study. Hence, it could be assumed that almost all of the marketed brands of Bangladesh maintained the national and international standard of iron content and National tea was revealed as the best marketed tea of Bangladesh in respect to iron content.

\subsection{Sugar}

Maximum amount of sugar content was estimated to be $6.87 \%$ in Seylon tea and minimum amount was estimated to be $4.39 \%$ in Magnolia tea. The mean value of sugar 
content of the studied brands was calculated to be $5.72 \%$ (Table 3). Sugar content of the studied brands of tea was found to be positive significantly $(\mathrm{P}<0.05)$ correlated with starch content only but negative significantly $(\mathrm{P}<0.05)$ correlated with $\mathrm{Na}$, fat and protein content (Table 4). Sugar level of the present experiment corroborates with the findings of Luo and Peng [19] who reported that the total sugar content was estimated to be $2.69 \%$ to $8.06 \%$ in five black tea samples of China.
Total sugar content of green tea purchased from the markets of Singapore was determined to be $1.0 \%$ in Longjing tea and $1.17 \%$ Bi Luo Chun tea respectively [42] which substantiates with the findings of the present study. Meanwhile, the sugar status of the commercial brand teas of Bangladesh is better comparable with the sugar status of the international standard. However, Seylon tea was recognized as the best marketed tea of Bangladesh in relation to sugar content.

Table 3. Variation of nutritional elements (sugar, fat, starch and protein) in seventeen marketed brands of black tea of Bangladesh.

\begin{tabular}{|c|c|c|c|c|}
\hline Brands & Sugar (\%) ${ }^{\dagger}$ & Fat $(\%)^{\dagger}$ & Starch $(\%)^{\dagger}$ & Protein $(\%)^{\dagger}$ \\
\hline Seylon & $6.87 \pm 0.21 \mathrm{~g}$ & $1.32 \pm 0.23 \mathrm{ab}$ & $0.168 \pm 0.012 \mathrm{de}$ & $4.87 \pm 0.12 \mathrm{~d}$ \\
\hline Tetley & $5.02 \pm 0.26$ bcd & $1.27 \pm 0.32 \mathrm{a}$ & $0.127 \pm 0.007 \mathrm{ab}$ & $5.06 \pm 0.11 \mathrm{e}$ \\
\hline Duncan & $6.23 \pm 0.24 \mathrm{f}$ & $1.75 \pm 0.19$ bcde & $0.169 \pm 0.008 \mathrm{de}$ & $5.58 \pm 0.11 \mathrm{fg}$ \\
\hline National & $5.54 \pm 0.13 \mathrm{e}$ & $2.47 \pm 0.35 \mathrm{~h}$ & $0.198 \pm 0.011 \mathrm{~g}$ & $6.63 \pm 0.14 \mathrm{j}$ \\
\hline Fresh & $6.36 \pm 0.26 \mathrm{f}$ & $1.14 \pm 0.25 \mathrm{a}$ & $0.143 \pm 0.012$ bc & $4.14 \pm 0.12 \mathrm{a}$ \\
\hline Teer & $6.29 \pm 0.30 \mathrm{f}$ & $1.46 \pm 0.20$ abc & $0.149 \pm 0.008 \mathrm{c}$ & $4.67 \pm 0.11 \mathrm{c}$ \\
\hline Finlay & $5.12 \pm 0.27$ cd & $2.26 \pm 0.22 \mathrm{fgh}$ & $0.186 \pm 0.009$ efg & $6.28 \pm 0.13 \mathrm{i}$ \\
\hline Starship & $6.76 \pm 0.26 \mathrm{~g}$ & $1.34 \pm 0.23 \mathrm{ab}$ & $0.157 \pm 0.012 \mathrm{~cd}$ & $4.36 \pm 0.12 \mathrm{~b}$ \\
\hline Ispahani & $5.37 \pm 0.16$ de & $2.15 \pm 0.22$ efgh & $0.175 \pm 0.011$ def & $5.88 \pm 0.15 \mathrm{~h}$ \\
\hline Cosmo & $4.86 \pm 0.16$ bc & $2.28 \pm 0.19 \mathrm{fgh}$ & $0.186 \pm 0.010$ efg & $6.21 \pm 0.12 \mathrm{i}$ \\
\hline Magnolia & $4.39 \pm 0.27 \mathrm{a}$ & $2.36 \pm 0.29$ gh & $0.192 \pm 0.007 \mathrm{fg}$ & $6.12 \pm 0.11 \mathrm{i}$ \\
\hline Danish & $6.62 \pm 0.23 \mathrm{fg}$ & $1.57 \pm 0.17 \mathrm{abcd}$ & $0.142 \pm 0.010 \mathrm{bc}$ & $4.39 \pm 0.13 \mathrm{~b}$ \\
\hline Shaw Wallace & $5.14 \pm 0.15$ cd & $1.89 \pm 0.23$ cdef & $0.189 \pm 0.010 \mathrm{fg}$ & $5.47 \pm 0.11 \mathrm{f}$ \\
\hline Pusti & $6.34 \pm 0.19 \mathrm{f}$ & $1.58 \pm 0.18$ abcd & $0.124 \pm 0.007 \mathrm{a}$ & $4.78 \pm 0.16 \mathrm{~cd}$ \\
\hline Kazi \& Kazi & $4.66 \pm 0.17 \mathrm{ab}$ & $1.96 \pm 0.20 \mathrm{defg}$ & $0.185 \pm 0.010$ efg & $5.68 \pm 0.12 \mathrm{~g}$ \\
\hline HRC & $6.85 \pm 0.08 \mathrm{~g}$ & $1.83 \pm 0.24$ cdef & $0.176 \pm 0.008$ ef & $5.56 \pm 0.14 \mathrm{fg}$ \\
\hline Lipton Taaza & $4.78 \pm 0.30$ bc & $2.37 \pm 0.33$ gh & $0.195 \pm 0.012 \mathrm{~g}$ & $6.23 \pm 0.13 \mathrm{i}$ \\
\hline Mean & $5.72 \pm 0.86$ & $1.82 \pm 0.47$ & $0.168 \pm 0.025$ & $5.41 \pm 0.76$ \\
\hline
\end{tabular}

${ }^{\dagger}$ Means (n=3) in table followed by a common letter are not significantly different $(\mathrm{P}>0.05)$. 
Table 4. Correlation coefficient matrix analysis between the minerals and nutritional elements of seventeen marketed brands of black tea of Bangladesh

\begin{tabular}{|c|c|c|c|c|c|c|c|c|c|c|}
\hline $\mathrm{N}$ & $\mathrm{P}$ & $\mathrm{K}$ & $\mathrm{Ca}$ & $\mathrm{Na}$ & $\mathrm{Fe}$ & $\mathrm{Sugar}$ & $\mathrm{Fat}$ & $\mathrm{Starch}$ & Protein & \\
\hline- & $0.82^{* *}$ & $0.81^{* *}$ & $0.75^{* *}$ & $0.82^{* *}$ & $0.85^{* *}$ & -0.44 & $0.77^{* *}$ & $-0.80^{* *}$ & $0.88^{* *}$ & $\mathrm{~N}$ \\
\hline & - & $0.80^{* *}$ & $0.80^{* *}$ & $0.85^{* *}$ & $0.83^{* *}$ & -0.41 & $0.83^{* *}$ & $-0.73^{* *}$ & $0.86^{* *}$ & $\mathrm{P}$ \\
\hline & - & $0.84^{* *}$ & $0.91^{* *}$ & $0.86^{* *}$ & -0.47 & $0.88^{* *}$ & $-0.80^{* *}$ & $0.89^{* *}$ & $\mathrm{~K}$ \\
\hline & & & - & $0.95^{* *}$ & $0.87^{* *}$ & -0.57 & $0.93^{* *}$ & $-0.86^{* *}$ & $0.94^{* *}$ & $\mathrm{Ca}$ \\
\hline & & & - & $0.93^{* *}$ & $-0.48^{*}$ & $0.96^{* *}$ & $-0.91^{* *}$ & $0.94^{* *}$ & Na \\
\hline & & & & & - & -0.41 & $0.91^{* *}$ & $-0.86^{* *}$ & $0.95^{* *}$ & Fe \\
\hline & & & & & - & $-0.54^{*}$ & $0.51^{*}$ & $-0.57^{*}$ & Sugar \\
\hline & & & & & & - & $-0.87^{* *}$ & $0.94^{* *}$ & Fat \\
\hline
\end{tabular}

*Significant at $\mathrm{p}<0.05 * *$ Significant at $\mathrm{p}<0.01$

\subsection{Fat}

The highest amount of fat content was determined to be $2.47 \%$ in National tea and the lowest amount was determined to be $1.14 \%$ in Fresh tea. The mean value of fat content of the studied brands was calculated to be $1.82 \%$ (Table 3). Fat content of the studied brands of tea was found to be positive significantly $(\mathrm{P}<0.05)$ correlated with $\mathrm{N}, \mathrm{P}, \mathrm{Ca}, \mathrm{Na}, \mathrm{Fe}$ and Protein but negative significantly $(\mathrm{P}<$ 0.05 ) correlated with sugar and starch content (Table 4).

Fat status of the present experiment substantiates with the findings of Adnan et al. [36] who found that fat content ranged from 0.94 to $2.03 \%$ with an average of $1.32 \%$ in ten popular commercial tea brands collected from different cities of Pakistan. Fat level of the present experiment corroborates with the findings of Luo and Peng [19] who reported that the fat content was estimated to be $0.88 \%$ to $1.44 \%$ in five black tea samples of China. So, it can be urged that the level of fat in the commercial brand teas of Bangladesh is consistent with the international standard and National tea was documented as the best commercial tea of Bangladesh while the fat content is concerned.

\subsection{Starch}

Maximum amount of starch content was estimated to be $0.198 \%$ in National tea and minimum amount was determined to be $0.124 \%$ in Pusti tea. The mean value of starch content of the studied brands was found to be $0.168 \%$ (Table 3). Starch content of the studied brands of tea was found to be positive significantly $(\mathrm{P}<0.05)$ correlated with sugar and $\mathrm{BI}$ contents only but negative significantly $(\mathrm{P}<$ 0.05 ) correlated with $\mathrm{N}, \mathrm{P}, \mathrm{K}, \mathrm{Ca}, \mathrm{Na}, \mathrm{Fe}$, fat and Protein contents (Table 4).
A little information is known about the starch content in the commercial brands of black tea in both Bangladesh as well as international level. However, the starch status of the present experiment substantiates with the findings of Luo and Peng [19] who reported that the starch content was estimated to be $0.027 \%$ to $0.20 \%$ in five black tea samples of China. More steps of new research on the starch status of marketed black tea should be taken for elevating the knowledge of nutritional status of tea. So, it is noticeable that starch content in the marketed teas of Bangladesh is similar to the other countries and all the marketed brands might have maintained the qualitative standard as regards starch content. As usual National tea was regarded as superior among the studied marketed teas of Bangladesh in pertaining to starch content.

\subsection{Protein}

The highest amount of protein content was determined to be $6.63 \%$ in National tea and the lowest amount was determined to be $4.14 \%$ in Fresh tea. The mean value of protein content of the studied brands was found to be $5.41 \%$ (Table 3). Protein content of the studied brands of tea was found to be positive significantly $(\mathrm{P}<0.05)$ correlated with starch and sugar contents only but negative significantly ( $\mathrm{P}$ $<0.05$ ) correlated with N, P, K, Ca, Na, Fe and fat contents (Table 4). The protein status of the present experiment substantiates with the findings of Luo and Peng [19] who reported that the protein content was estimated to be $4.76 \%$ to $8.98 \%$ in five black tea samples of China.

Protein levels of the present experiment authenticate the findings of Adnan et al. [36] who found that protein content ranged from 0.87 to $1.03 \%$ with an average of $0.96 \%$ in ten popular commercial tea brands collected from 
different cities of Pakistan. Robb and Brown [21] and Peterson et al. [22] reported that Protein content in black tea and green tea was determined to be $6.0 \%$ each which is in full accordance with the protein status of the present study. So far the protein content is concerned, all the tested brands demonstrated reasonably high amount of protein content which covers the level of Bangladesh tea standard and certainly comparable with the standard of other tea producing countries. Therefore, Present study suggests that National brand tea is superior in relation to protein content among the studied marketed brands of tea in Bangladesh.

\subsection{Comparison of Price with Total Mineral and Nutritional Status}

The market prices of seventeen marketed teas of Bangladesh are shown in Table 1. It is evident from the results that the maximum price/kg was observed in Kazi \& Kazi tea $(650 \mathrm{Tk} / \mathrm{kg}$ ) and the minimum price was observed in Danish tea (298 Tk/kg) (Figure 2). The results imply that the highest amount of total minerals and nutritional elements (total of N, P, K, Ca, Na, Fe, sugar, fat, starch and protein) was perceived to be $26.94 \%$ in National tea and the lowest amount was perceived to be $19.48 \%$ in Fresh tea (Figure 1). It is obvious from the result that market price of the studied seventeen marketed brand teas of Bangladesh was almost dependent on the total amount of minerals and nutritional elements. The sequence of biochemical composition in all the studied brands of tea followed the sequence of price. This result corroborates with the findings of Alam et al. [30] and Alam et al. [32]. The market price of all the studied brands of tea was found to be changed positively with the nutritional status. The results also indicate that the higher the minerals and nutritional element in the tea of brands was as the higher the price.

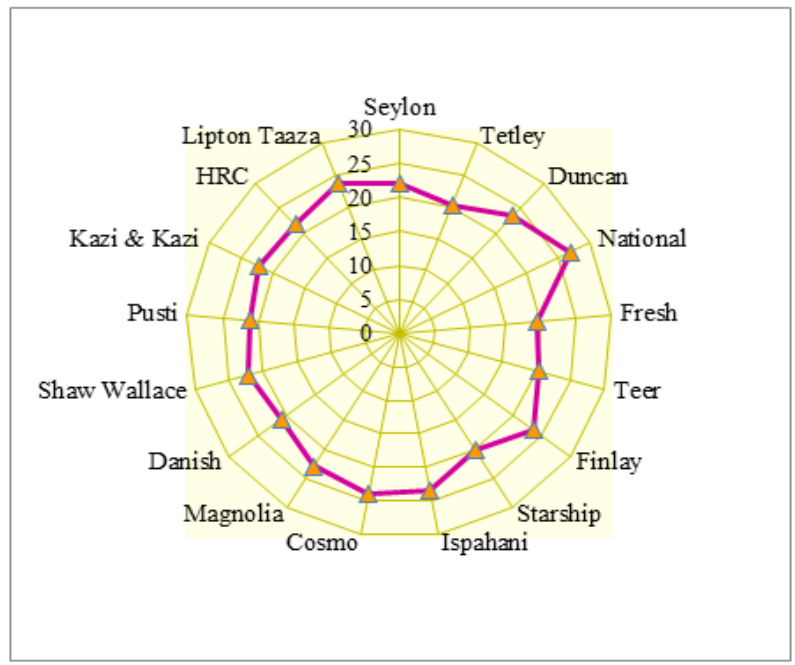

Figure 1. Variation of total nutritional elements in seventeen marketed brands teas of black tea of Bangladesh.

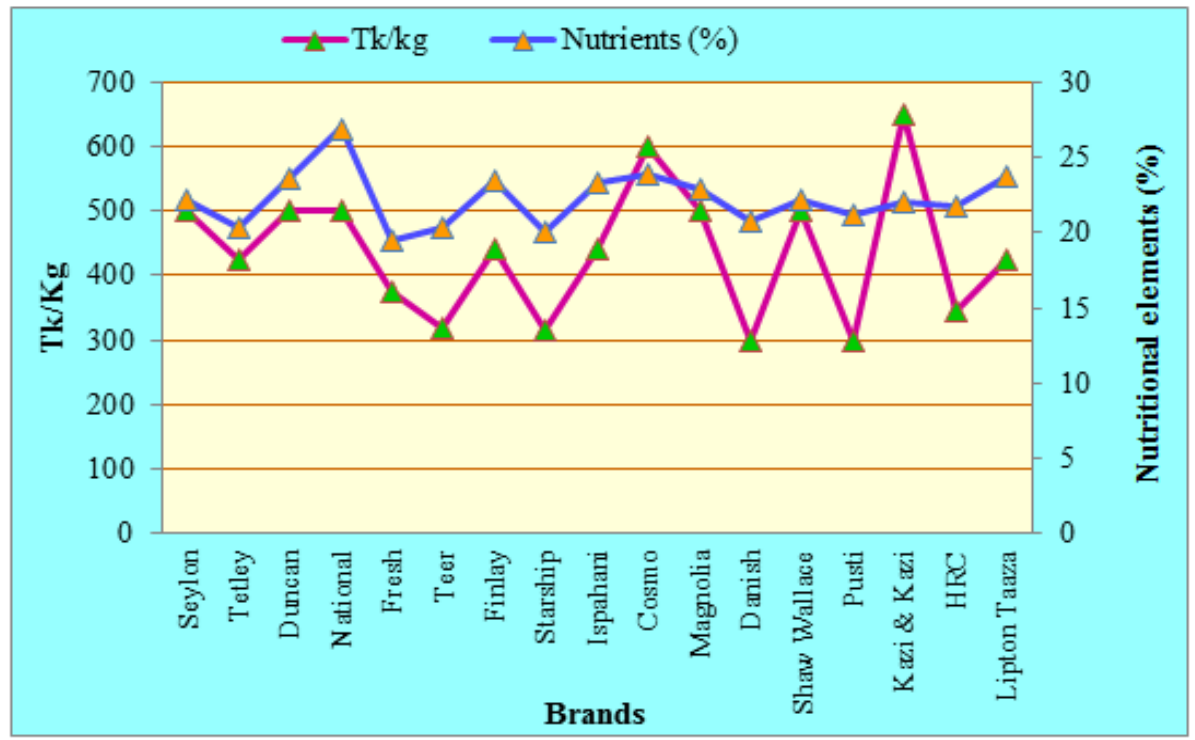

Figure 2. Comparison of nutritional elements and market price of seventeen marketed brands of black tea of Bangladesh. 


\section{Conclusions}

The present study concludes that all the studied minerals and nutritional parameters of the seventeen marketed brands of black tea of Bangladesh varied significantly with brands. The average quantity of the studied parameters $(\mathrm{N}$, $\mathrm{P}, \mathrm{K}, \mathrm{Ca}, \mathrm{Na}, \mathrm{Fe}$, Sugar, Fat, Starch and Protein) was determined to be $5.11 \%, 0.24 \%, 2.21 \%, 1.35 \%, 0.16 \%$, $0.057 \%, 5.72 \%, 1.82 \%, 0.168 \%$ and $5.41 \%$ respectively. The magnitude of each minerals and nutritional element was found to be reasonably high and better comparable with the nutritional status of black tea produced as well as marketed in other countries. The market price of all the studied brands of tea was found to be changed positively with the nutritional status. In other words, the market price of all the studied brands of tea was observed to be dependent on the qualitative status. The present experiment further concludes that in relation to total nutritional elements (sum of N, P, K, Ca, Na, Fe, Sugar, Fat, Starch and Protein), National tea was found to be the most excellent among the seventeen marketed brands of black tea of Bangladesh and all the marketed brand teas can be ranked as National $>$ Cosmo $>$ Lipton Taaza $>$ Duncan $>$ Finlay $>$ Ispahani $>$ Magnolia $>$ Shaw Wallace $>$ Seylon $>$ Kazi \& Kazi $>$ HRC $>$ Pusti $>$ Danish $>$ Tetley $>$ Teer $>$ Starship $>$ Fresh.

\section{Acknowledgements}

The authors are thankful to the Department of Botany, University of Chittagong, Bangladesh for providing all sorts of required facilities to conduct this study.

\section{REFERENCES}

[1] S Khokhar and S G M Magnusdottir, "Total Phenol, Catechin, and Caffeine Contents of Teas Commonly Consumed in the United Kingdom, " Journal of Agricultural and Food Chemistry, vol. 50, pp. 565-570, 2002

[2] D Balentine, "Tea and health. " Critical Reviews in Food Science and Nutrition, vol. 37, pp. 691-692, 1997

[3] Q K Cheng and Z M Chen, " Tea and health. Beijing, China ": Press of Chinese Agricultural Acience. 1994

[4] Wu, C.D. and Wei, G.X. 2002. Tea as a functional food for oral health. Journal of Nutrition. 18: 443-444.

[5] Costa, L. M.; Gouveia, S. T.; Nobrega, J. A. 2002. Comparison of heating extraction procedures for $\mathrm{Al}, \mathrm{Ca}$, $\mathrm{Mg}$ and $\mathrm{Mn}$ in tea samples. Anal. Sci., 18: 313-318.

[6] Zuo, Y., Chen, H. And Deng, Y. 2002. Simultaneous Determination of Catechins, Caffeine, and Gallic Acid in Green, Oolong, Black, and Pu-Erh Teas by HPLC with Photodiode Detection. Talanta. 57: 307-316.
[7] Dutta R., Stein A., Smaling E.M.A., Bhagat R.M. and Hazarika M., 2010. Effects of Plant age and environmental and management factors on tea yield in Northeast India. Agron. J. 102: 1290-1301.

[8] Eroğlu, H.E. 2011. The Cytogenetic Effects of Black Tea and Green Tea on Cultured Human Lymphocytes. Brazilian Arch. Biol. Technol., 54:1159-1165.

[9] Xie M, Xie Von Bohlen A, Klockenkamper R, Jian X, Gunther K (1998): Multielement analysis of chinese tea (Camellia sinensisL.) by total reflection Xray fluorescence. Z. Lebensm Unters Forsch A. 207: 31-38.

[10] Fernandez PL, Pablos F, Martin MJ, Gonzalez AG (2002): Multi element analysis of tea beverages by inductively coupled plasma atomic emission spectrometry. Food Chem 76: $483-489$

[11] Erturk, Y., Ercisili, S., Sengul, M., Eser, Z., Hzendar, A. and Turan, M. 2010. Seasonal Variation of total phenolic, antioxidant ctivityand minerals in tea Shoots (Camellia sinensis var. sinensis), Pak. J. Pharm. Sci. 23(1): 69-74.

[12] Stagg, G.V. and Millin, D.J. 1975. The nutritional and therapeutic value of tea - a review. J. Sci. Food Agric. 26: 1439-1459.

[13] Wilison C. 1975. Studies on the mineral nutrition of tea 11. Nitrogen, plant and soil.; 42: 501-516.

[14] Chaudhury, S.H. 1983. Nutrient requirements of tea plants (Camellia sinensis L.). Ph. D. Thesis, Reading University, England.

[15] Kacar, B., Przemeck, E., Ozgumus, A., Turan, C., Katkat, A.V. and Kayikcioglu, I. 1979. A study on the microelement necessityof tea plants and soils. Tubitak, TOAG-321, Ankara: 1-67.

[16] Mann, H.H. and Gokhale, N.G. 1960. Soils of the tea growing tracts of India. Journal of the Indian Society of Soil Science. VIII.

[17] Chowdhury, M.A.M. and Alam, K.M.M. 2001. Screening for qualitative and quantitative status of green tea in ten clonal agro-types cultured at BTRISS, ODAHLEA, Bangladesh. Proceedings of 2001 international conference on O-CHA (tea) culture and science, Shizuoka, Japan. session-II (production): 41-45.

[18] Kottur, G., Venkatesan, S., Shanmugasundaram R., Kumar, S. and Murugesan, S. 2010. Influence of seasons on biochemical parameters of green shoots and quality parameters of made tea under south Indian conditions. J. Biosc i. Res. 1(2):74-8.

[19] Luo, M. And Peng, H. 2012. Study on Determination of Contents of the Main Components of Tea Polyphenols. International Journal of Bioscience, Biochemistry and Bioinformatics. 2(6): 433-437.

[20] Bhatia, I.S. 1964. Biochemical investigations in relation to tea manufacture. Two and A Bud. 11(1): 8-15.

[21] Robb, C. S. and Brown, P.R. 2001. Catechins in Tea: Chemistry and Analysis. Advances in Chromatography. 41: 379-410.

[22] Peterson J., Dwyer, J., Bhagwat, S., Haytowitz, D., Holden, J., Eldridge, A. L., Aladesamni, J. 2005. Major Flavonoids 
in Dry Tea. Journal of Food Composition and Analysis. 18: 487-501.

[23] M. R. Karim, M. A. Choudhury, A. K. M. G. Kibria and M. H. Rahman. Crude fibre and TF-TR contents in Bangladesh tea and their industrial significance. Tea J. of Bangladesh. Vol. 36(1\&2), 39-46, 2000.

[24] K. M. M. Alam and M. A. M. Chowdhury. Dynamics of caffeine and polyphenol in pluckable tea shoots of ten clonal agrotypes cultured at BTRISS, Odahlea, Bangladesh. International Journal of Tea Science. Vol. 6(4), 37-43, 2007.

[25] K. M. M. Alam, R. Ahmed, C. Rashid, M. S. Uddin and M. A. M. Chowdhury. Screening for Qualitative Status of Five Popular Marketed Brands of Tea Produced in Bangladesh. Universal Journal of Plant Science. Vol. 3(3), 43-48, 2015.

[26] Jackson, M.L. 1973. Soil Chemical Analysis, Prentice Hall of India Private Limited, New Delhi.

[27] Black, C. A. 1965. Soil Plant Relationship, 2nd Edn, John Wiley and Sons, Inc. N. Y.

[28] Jackson, M.L. 1958. Soil Chemical Analysis, Prentice Hall Inc. Englas Cliffa N. J. U.S.A.

[29] Owuor, P.O. and Wanyoka, J.K. 1983. Fertilizer use advisory service a reminder to farmers. Tea 3(2): 3-7.

[30] K. M. M. Alam, I. Farjana, T. P. Rumi and M. S. Uddin. Screening for the active components of seven marketed brands of Shaw Wallace tea produced in Bangladesh. Journal of Pharmacognosy and Phytochemistry. Vol. 7(2), 2239-2248, 2018.

[31] Alam, K.M.M., Akhter, R., Chowdhury S. and Uddin, M. S. 2018. Evaluation for active components and nutrient elements in six marketed brands of Ispahani tea grown in Bangladesh. Sch. Acad. J. Pharm. 7(1): 11-19.

[32] K. M. M. Alam, T. P. Rumi, I. Farjana and M. S Uddin. Evaluation for the Qualitative Status of Eight Marketed Teas of Finlay Brand Produced In Bangladesh. Journal of Pharmacognosy and Phytochemistry.; Sec. B, Vol. 7(2), 135-153, 2018.

[33] Ozgumus, A., Turan, C. and Kacar, B. 1982. The phosphorus situation of tea soils in Turkey. Doga. 6: 201-203.

[34] K M Mesbaul Alam, R. Akhter, S. Chowdhury and M. S. Uddin. 2018. Evaluation for active components and nutrient elements in six marketed brands of Ispahani tea grown in Bangladesh. Sch. Acad. J. Pharm., 2018; 7(1):11-19,

[35] KM Mesbaul Alam, S Chowdhury, R Akhter and MS Uddin. 2018. Qualitative and quantitative evaluation for caffeine, phenolic compounds and nutrient elements in six marketed brands of Kazi and Kazi tea produced in Bangladesh. Journal of Pharmacognosy and Phytochemistry, 2018; 7(3): 2460-2467.

[36] Adnan M., Ahmad A., Ahmed A., Khalid N., Hayati I. and Ahmed I. 2013. Chemical composition and sensory evaluation of tea (Camellia sinensis) commercialized in Pakistan. Pak. J. Bot. 45(3): 901-907.

[37] Street R., Sszáková J., Drábek O., Mládková L. 2006. The status of micronutrients $(\mathrm{Cu}, \mathrm{Fe}, \mathrm{Mn}, \mathrm{Zn})$ in tea and tea infusions in selected samples imported to the Czech
Republic. Czech J. Food Sci. 24: 62-71.

[38] Marbaniang, D.G., Baruah, P., Decruse, R., Dkhar, E.R., Diengdoh, D.F. and Nongpiur, C.L. 2011. Study of trace metal (Cr, Mn, Fe, Co, Ni, Cu, Zn and Cd) composition in tea available at Shillong, Meghalaya, India.International Journal of Environmental Protection. 1(1): 13-21.

[39] Achudume C.A. and Owoeye D. 2010. Quantitative assessment of heavy metals, Acids and Sugars in Green Tea by Anion Exchange Chromatography with Pulsed Amperometric Detection. Journal of Chromatography, 982: 237-244.

[40] Moroydor Derun, E., Kipcak, A.S., Dere Ozdemir, O., Piskin, M.B. 2012. Cr, Fe and Se Contents of the Turkish Black and Green Teas and the Effect of Lemon Addition.World Academy of Science, Engineering and Technology. 6: 11-23.

[41] Mandal, S., Banjanin, B., Kujović, I. and Malenica, M. 2015. Spectrophotometric determination of total iron content in black tea. Bulletin of the Chemists and Technologists of Bosnia and Herzegovina. 44: 29-32. 